\title{
Hubungan Indeks Massa Tubuh dan Tercapainya Remisi pada Anak Penderita Leukemia Limfoblastik Akut
}

\author{
Venita S. Pojoh, ${ }^{1}$ Max F. J. Mantik, ${ }^{2}$ Jeanette I. Ch. Manoppo $^{2}$
}

\author{
${ }^{1}$ Program Studi Pendidikan Dokter Fakultas Kedokteran Universitas Sam Ratulangi Manado \\ ${ }^{2}$ Bagian Ilmu Kesehatan Anak Fakultas Kedokteran Universitas Sam Ratulangi Manado \\ Email: venitapojoh@gmail.com
}

\begin{abstract}
Acute lymphoblastic leukemia (LLA) is the most common type of leukemia in children. Until now chemotherapy is still used as the main treatment. One aspect that affects the success of chemotherapy is body mass index (BMI). BMI values in children with LLA tend to be unstable, low, or high. This is triggered by natural immune cell disorders which have an impact on increasing cytokines and side effects of treatment. This study was aimed to determine the relationship between BMI and the achievement of remission in children with ALL. This was a retrospective and analytical study with a cross-sectional design. Samples were ALL patients who had been given induction phase of chemotherapy during 2015-2018 based on medical records at Estella Children's Cancer Center, Prof. Dr. R. D. Kandou Hospital Manado. The results obtained 52 samples which were evaluated and analyzed to determine the relationship of BMI and the achievement of remission. The Spearman correlation test showed a significant value of $p=0.799$ ( $p>0.05)$. In conclusion, there was no relationship between BMI and the achievement of remission in children with ALL
\end{abstract}

Keywords: body mass index, remission, acute lymphoblastic leukemia

\begin{abstract}
Abstrak: Leukemia limfoblastik akut (LLA) merupakan jenis leukemia yang paling sering terjadi pada anak-anak. Sampai saat ini kemoterapi masih dipakai sebagai pengobatan utama. Salah satu aspek yang memengaruhi keberhasilan kemoterapi yaitu indeks massa tubuh (IMT). Nilai IMT pada anak penderita LLA cenderung tidak stabil, bisa kurang tetapi juga lebih. Hal ini dipicu oleh gangguan sel imun alami yang dialami penderita kemudian berdampak terhadap peningkatan sitokin serta efek samping pengobatan. Penelitian ini bertujuan untuk mengetahui hubungan antara IMT dan tercapainya remisi pada anak penderita LLA. Jenis penelitian ialah analitik retrospektif dengan desain potong lintang. Sampel penelitian ialah pasien LLA yang telah diberikan kemoterapi fase induksi periode 2015-2018, didapatkan dari rekam medik di Pusat Kanker Anak Estella RSUP Prof Dr. R. D. Kandou Manado. Hasil penelitin mendapatkan 52 sampel, kemudian dievaluasi dan dianalisis untuk melihat hubungan IMT dan tercapainya remisi pada sampel. Hasil uji korelasi Spearman menunjukkan nilai $\mathrm{p}=0,799(\mathrm{p}>0,05)$. Simpulan penelitian ini ialah tidak terdapat hubungan antara IMT dan tercapainya remisi pada anak penderita LLA.
\end{abstract}

Kata kunci: Indeks massa tubuh, remisi, leukemia limfoblastik akut

\section{PENDAHULUAN}

Jenis kanker yang paling sering ditemukan pada anak-anak yaitu leukemia akut. ${ }^{1}$ Berdasarkan tipe sel, leukemia akut dibagi atas leukemia limfoblastik akut (LLA) dan leukemia mieloblastik akut (LMA). Tipe LLA merupakan leukemia yang paling banyak ditemukan yaitu sebesar $88 \%$. ${ }^{2,3}$ Leukemia limfoblsatik akut adalah suatu keganasan hematologis yang ditandai oleh proliferasi sel limfoid yang belum matang dalam darah tepi, sumsum tulang, dan organ lainnya. ${ }^{2}$

Secara global, angka kejadian leu- 
kemia akut rata-rata 4-4,5 per 100.000 anak per tahun pada anak usia di bawah 15 tahun. ${ }^{2}$ Menurut American Cancer Society tahun 2014, diperkirakan angka kejadian LLA mencapai 2.670 kasus dan angka kematian mencapai 1.440 kasus. Prevalensi kejadian LLA pada anak yaitu sebesar $75 \%$ dibandingkan jenis leukemia yang lain. ${ }^{4} \mathrm{Di}$ Indonesia, angka kejadian leukemia bertambah setiap tahun. Menurut Yayasan Onkologi Anak Indonesia tahun 2012, kasus kanker pada anak sebanyak 11.000 dan diperkirakan sekitar $70 \%$ merupakan kasus leukemia akut. ${ }^{5}$ Berdasarkan data yang tercatat di Sistem Registrasi Kanker di Indonesia tahun 2005-2007 dalam Kemenkes tahun 2013, angka keja-dian pada anak usia 0 sampai 17 tahun adalah 9 per 100.000 anak dengan prevalensi leukemia akut (kanker tertinggi pada anak) adalah 2,8 per 100.000 anak-anak dan data yang tercatat pada riskesdas tahun 2013, menunjukkan provinsi Sulawesi Utara pada kedudukan tertinggi sebanyak $0,11 \%{ }^{6}$ Berdasarkan prevalensi tersebut, kasus LLA dibandingkan kasus LMA.

Sampai saat ini, kemoterapi masih dipakai sebagai pengobatan utama pada penyakit LLA. Kemoterapi merupakan terapi kuratif spesifik bisa menyembuhkan leukemia yang meliputi 3 tahapan yaitu induksi remisi, intensifikasi, profilaksis susunan saraf pusat dan rumatan. Kemoterapi merupakan salah satu aspek yang dapat menentukan tercapainya remisi pada penderita LLA. Remisi merupakan kejadian dimana hilangnya gejala klinis dari penyakit, pada pemeriksaan gambaran darah tepi didapatkan hasil normal, dan terjadinya penurunan jumlah sel leukemia. Kemungkinan hasil yang akan dicapai yaitu remisi komplit tetapi bisa juga seperti yang terjadi pada beberapa kasus leukemia limfoblastik akut hasil yang didapatkan yaitu remisi parsial atau gagal. ${ }^{2}$ Pasien dinyatakan remisi komplit jika setelah menjalani kemoterapi, pasien sudah tidak menunjukkan keluhan dan telah bebas dari gejala klinik leukemia, ditemukan jumlah sel blas $<5 \%$ dari sel berinti pada aspirasi tulang belakang, hemoglobin $>12 \mathrm{~g} / \mathrm{dl}$ tanpa trans- fusi, hitung jenis leukosit didapatkan jumlah leukosit $>3000 / \mu 1$, jumlah granulosit $2000 / \mu 1$, jumlah trombosit $>100.000 / \mu 1$, dan hasil didapatkan normal pada saat pemeriksaan cairan serebrospinal. $^{7}$

Relaps dapat terjadi pada pasien LLA yang telah mencapai remisi. Belum diketahui dengan pasti penyebab terjadinya relaps. Diperkirakan keparahan stadium kanker, usia, jenis kelamin, kadar hemoglobin dalam darah, kadar albumin, dan jumlah leukosit merupakan faktor-faktor yang menimbulkan risiko relaps. ${ }^{8}$ Tersedia pula terapi suportif yang digunakan bila terdapat penyakit lain yang menyertai leukemia dan jika terjadi komplikasi. ${ }^{2}$

Hasil pengobatan LLA sering dihubungkan dengan status gizi anak. Berdasarkan penelitian yang dilakukan Lange et al ${ }^{10}$ dikatakan bahwa anak yang memiliki status gizi kurang atau buruk bahkan gizi lebih mempunyai survival yang lebih pendek dan treatment-related mortality yang lebih tinggi dibandingkan dengan anak yang mempunyai gizi baik. ${ }^{9-10}$ Penelitian yang dilakukan Burturini ${ }^{11}$ melaporkan bahwa penderita yang memiliki risiko tinggi untuk relaps dan event-free survival yang rendah didapatkan pada anak usia $>10$ tahun atau lebih dengan obesitas atau BB $>60 \mathrm{~kg}$. Penelitian selanjutnya dilakukan oleh Gatot dan Windiastuti ${ }^{12}$ tahun 2006 dan mendapatkan kelompok risiko tinggi lebih besar untuk mengalami relaps yaitu $18 \%$ dibandingkan pasien yang termasuk kelompok risiko biasa yaitu $17,8 \%$, pada pasien obesitas sekitar $30 \pm 4 \%$ dan pasien non obesitas $20 \pm 1 \%$. Overall survival untuk pasien obesitas ialah $68 \pm 5 \%$ dan non obesitas $80 \pm 1 \%$ sedangkan event-free survival untuk pasien obesitas $63 \pm 5 \%$ dan non obesitas $74 \pm 1 \% .^{12}$ Tetapi sebaliknya yang ditemukan oleh Hijaya et $\mathrm{al}^{13}$ pada penelitiannya yaitu tidak terdapat perbedaan bermakna overall survival, event-free survival, dan cumulative incidence of relaps antara obesitas dan non obesitas.

Penelitian yang dilakukan oleh Rachmawati ${ }^{5}$ di RSUD Dr. Moewardi Surakarta menyatakan di salah satu rumah sakit ditemukan bahwa anak yang memiliki 
status gizi buruk banyak menimbulkan keluhan saat di rumah sehingga orang tua lebih sering membawa anaknya ke rumah sakit sedangkan anak yang memiliki status gizi baik, tidak ada keluhan saat di rumah sehingga datang ke rumah sakit saat kemoterapi saja. Hal ini berpengaruh terhadap tercapainya remisi setelah melewati tahapan pengobatan.

Oleh karena itu, sangat penting untuk dilakukan pemantauan status gizi pada anak penderita leukemia setelah didiagnosis dan selama mendapatkan pengobatan. Untuk mengetahui status gizi maka perlu dilakukan pengukuran indeks massa tubuh (IMT). Menghitung IMT anak menggunakan rumus berat badan dalam kilogram dibagi dengan tinggi badan dalam meter kuadrat. ${ }^{14}$ Pencapaian remisi merupakan langkah awal dalam perjalanan pengobatan, dan bagi penderita yang gagal mencapai remisi mempunyai prognosis buruk. ${ }^{15}$

Berdasarkan beberapa penelitian sebelumnya bahwa terdapat hubungan antara status gizi anak dan pencapaian remisi pada penyakit LLA, maka penulis tertarik untuk meneliti hubungan IMT dan tercapainya remisi pada anak penderita LLA di RSUP Prof. Dr. R. D. Kandou Manado.

\section{METODE PENELITIAN}

Jenis penelitian yang digunakan ialah analitik retrospektif dengan desain potong lintang. Pengumpulan data IMT pasien anak penderita LLA yang dirawat di Pusat Kanker Anak Estella baik yang sudah dan belum mengalami remisi pada periode 2015-2018 menggunakan data sekunder yang berasal dari rekam medik di Instalasi rekam medik RSUP Prof. Dr. R.D. Kandou Manado.

Populasi penelitian ialah seluruh pasien LLA di Pusat Kanker Anak Estella RSUP Prof. Dr. R. D. Kandou Manado sedangkan sampel penelitian ialah pasien LLA yang telah diberikan kemoterapi fase induksi periode 2015-2018. Metode pengambilan sampel ialah purposive sampling. Analisa data diolah menggunakan SPSS untuk mengetahui korelasi variabel penelitian. Uji statistik dilakukan dengan uji korelasi Spearman dengan bantuan komputer menggunakan software SPSS.

Penelitian ini telah mendapat persetujuan dari Komisi Etik Penelitian Kesehatan RSUP Prof. Dr. R. D. Kandou Manado, dengan nomor keterangan layak etik yaitu No. 055/EC/KEPK-KANDOU/X/2019.

\section{HASIL PENELITIAN}

Penelitian ini dilakukan pada pasien LLA yang dirawat di Pusat Kanker Anak Estella RSUP Prof. Dr. R. D Kandou Manado periode Januari 2015 - Desember 2018. Pada penelitian ini didapatkan sebanyak 52 sampel.

Tabel 1 memperlihatkan karakteristik sampel. Berdasarkan usia pasien, dari 52 sampel distribusi tertinggi di dapat-kan pada anak usia 6-11 tahun yaitu 24 anak $(46,2 \%)$. Berdasarkan jenis kelamin, didapatkan pasien laki-laki lebih banyak dibandingkan perempuan. Jumlah pasien lakilaki sebanyak 32 anak $(61,5 \%)$ dan perempuan sebanyak 20 anak $(38,5 \%)$.

Tabel 1. Karakteristik sampel

\begin{tabular}{cc}
\hline Karakteristik sampel & $\mathbf{n}(\%)$ \\
\hline Usia & \\
$1-5$ & $22(42,3)$ \\
$6-11$ & $24(46,2)$ \\
$12-18$ & $6(11,5)$ \\
Jenis kelamin & \\
Laki-laki & $32(61,5)$ \\
Perempuan & $20(38,5)$ \\
Total & $52(100)$ \\
\hline
\end{tabular}

Tabel 2 memperlihatkan distribusi sampel berdasarkan kategori IMT. Berdasarkan kategori IMT, didapatkan pasien yang tergolong dalam kategori underweight yang terbanyak, yaitu 38 anak $(73,1 \%)$, sedangkan yang obesitas tidak ada.

Tabel 3 menunjukkan hubungan IMT dengan remisi pada anak penderita LLA. Dari 52 sampel, pasien yang tergolong dalam kategori underweight dan telah mencapai remisi sebanyak 18 anak $(47,4 \%)$ dan tidak mencapai remisi sebanyak 20 anak $(52,6 \%)$. Pasien yang tergolong dalam kategori normal yang telah mencapai remisi 
sebanyak $3(27,3 \%)$ dan tidak mencapai remisi sebanyak $8(72,7 \%)$. Semua pasien yang tergolong dalam kategori overweight telah mencapai remisi yaitu sebanyak 3 orang (100\%). Tidak terdapat pasien dalam kategori obesitas. Uji statistik korelasi Spearman mendapatkan nilai $\mathrm{r}=0,040$ yang menunjukkan bahwa kekuatan korelasi antara IMT dan remisi lemah. Diperoleh nilai $\mathrm{p}=0,799(\mathrm{p}>0,05)$ yang berarti tidak terdapat hubungan bermakna antara IMT dan tercapainya remisi pada penderita LLA.

Tabel 2. Distribusi sampel berdasarkan kategori IMT

\begin{tabular}{cc}
\hline Kategori IMT & $\mathbf{n}(\%)$ \\
\hline Underweight & $38(73,1)$ \\
Normal & $11(21,2)$ \\
Overweight & $3(5,7)$ \\
Obesitas & $0(0)$ \\
Total & $52(100)$ \\
\hline
\end{tabular}

\section{BAHASAN}

Penelitian ini dilakukan di RSUP Prof. Dr. R. D. Kandou Manado. Sampel dalam penelitian ini ialah 52 pasien anak LLA yang telah diberikan kemoterapi fase induksi periode 2015-2018. Penentuan sampel penelitian yaitu dengan menggunakan metode purposive sampling yaitu salah satu teknik non random sampling dimana peneliti menentukan jumlah sampel dengan menetapkan ciri-ciri khusus dalam hal ini yaitu kriteria eksklusif dan inklusif yang sesuai dengan tujuan penelitian sehingga dapat menjawab permasalahan penelitian. ${ }^{16}$ Dari 52 sampel tersebut dilakukan peninjauan dari segi usia, jenis kelamin dan nilai IMT yang telah di kategorikan berdasarkan kategori underweight, normal, overweight dan obesitas dari perhitungan antara berat-badan dalam kilogram dibagi tinggi badan pasien dalam sentimeter pangkat dua.

Berdasarkan usia didapatkan bahwa anak-anak dari semua golongan usia terkena dan usia 4 tahun memiliki distribusi tertinggi yaitu sebanyak 9 anak $(17,3 \%)$. Hal ini sesuai dengan penelitian Rudolph ${ }^{17}$ bahwa puncak usia timbulnya penyakit LLA ialah antara usia 3-5 tahun. Penelitian yang dilakukan oleh Wong et al $^{18}$ menyatakan bahwa puncak LLA pada anak yaitu usia 2-6 tahun. Sampai saat ini, alasan mengapa anak-anak rentan untuk mengalami LLA belum diketahui dengan pasti, namun faktor lingkungan, faktor genetik serta keadaan imunodefisiensi telah menjadi faktor predisposisi terhadap terjadinya leukemia. Berbagai upaya yang dilakukan untuk melihat hubungan virus dengan terjadinya leukemia, namun tidak ada bukti langsung yang menghubungkan segala virus dengan jenis leukemia yang sering terjadi, namun dicurigai mutasi spontan sebagai salah satu hipotesis penyebab mengapa LLA rentan terjadi pada anak. Berdasarkan teori, sel progenitor limfoid yang merupakan sel target untuk LLA, memiliki kecepatan proliferasi yang tinggi. Pada masa anak-anak awal terdapat kecenderungan tinggi untuk pengaturan kembali gen, sehingga anak lebih rentan untuk mengalami mutasi dan lebih rentan pula mengalami penyakit LLA. ${ }^{17}$ Dalam penelitian ini, usia penderita dikelompokkan menjadi tiga kelompok yaitu kelompok usia 1-5 5 tahun, usia 6-11 tahun, dan usia 12-18 tahun. Berdasarkan karakteristik usia didapatkan frekuensi tertinggi pada kategori usia 6-11 tahun yaitu sebanyak 24 anak $(46,2 \%)$.

Tabel 3. Hubungan indeks massa tubuh dengan remisi

\begin{tabular}{ccccc}
\hline \multirow{2}{*}{ IMT } & \multicolumn{2}{c}{ Remisi } & \multirow{2}{*}{ Nilai r } & \multirow{2}{*}{ Nilai p } \\
\hline Underweight & $18(47,4 \%)$ & $20(52,6 \%)$ & & \\
Normal & $3(27,3 \%)$ & $8(72,7 \%)$ & 0,040 & 0,799 \\
Overweight & $3(100 \%)$ & 0 & & \\
Obesitas & 0 & 0 & & \\
\hline
\end{tabular}


Ditinjau dari segi distribusi jenis kelamin anak, yang tertinggi yaitu laki-laki sebanyak 32 anak $(61,5 \%)$ dan untuk perempuan hanya 20 anak $(38,5 \%)$. Kondisi ini sesuai dengan penelitian Tehuture ${ }^{19}$ yang melaporkan bahwa laki-laki merupakan jenis kelamin yang paling banyak dibandingkan dengan perempuan sehingga didapatkan nilai ratio laki-laki:perempuan yaitu 1:2. Penelitian Ramadhani ${ }^{20}$ melaporkan bahwa dari 30 sampel didapatkan 19 anak laki-laki dan 11 anak perempuan. Hal ini sesuai dengan beberapa kepustakaan yang menyatakan bahwa laki-laki cenderung lebih banyak dibandingkan perempuan dengan rasio laki-laki dan perempuan

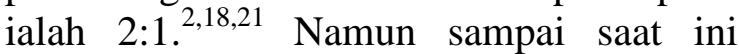
belum diketahui pasti alasan mengapa anak laki-laki cenderung lebih sering mengalami LLA dibandingkan anak perempuan.

Berdasarkan kategori status gizi menggunakan nilai IMT, didapatkan distribusi tertinggi ialah kategori underweight yaitu sebanyak 38 anak $(73,1 \%)$. Kategori yang lain didapatkan lebih sedikit, yaitu untuk kategori normal sebanyak 11 anak $(21,2 \%)$, kategori overweight sebanyak 3 anak $(5,7 \%)$, sedangkan obesitas tidak didapatkan pada 52 sampel. Kondisi ini juga sesuai dengan penelitian Rachmawati $^{5}$ mengenai hubungan status gizi dengan frekuensi hospitalisasi pasien LLA pada anak prasekolah di RSUD Dr. Moewardi yang mendapatkan distribusi tertinggi status gizi anak pada kategori status gizi kurus. Untuk kategori kurus didapatkan sebanyak 9 responden $(60 \%)$ dan normal sebanyak 6 responden (40\%). Dalam hasil penelitian tersebut juga disimpulkan bahwa anak presekolah LLA yang mengalami status gizi kurang akan semakin sering melakukan hospitalisasi. Perbedaan dengan penelitian ini terletak pada pengelompokkan status gizi. Dalam penelitian yang dilakukan oleh Rachmawati ${ }^{5}$ kategori status gizi hanya dikelompokkan berdasarkan 2 kategori yaitu kurus dan normal. Hal ini sesuai dengan pernyataan Permono $^{2}$ yang menyatakan anak dengan LLA rentan mengalami penurunan status gizi karena efek pengobatan yang mengakibatkan gangguan saluran cerna berupa anoreksia ringan, mual, muntah bahkan diare, selain dapat mengalami penurunan berat badan. Efek pengobatan dalam penggunaan kortikosteroid jangka panjang telah menunjukkan peningkatan asupan energi dan persentase lemak tubuh pada anak dengan LLA.

Untuk mencapai tahap remisi anak penderita LLA membutuhkan kemoterapi sebagai pengobatan utama. Pada umumnya, pasien LLA akan mendapatkan kemoterapi induksi dengan tiga atau empat agen obat kemoterapi. Setelah induksi, remisi akan tercapai. Setelah pencapaian remisi dilanjutkan kemoterapi fase konsolidasi dan kemoterapi fase pemeliharan atau rumatan sebagai terapi lanjutan untuk memelihara remisi dan selanjutnya untuk mengurangi jumlah sel leukemia. $^{22}$

Pada penelitian Wong et al $^{18}$ setiap kali terapi akan disertai dengan sejumlah efek samping yang dapat diperkirakan tergantung jenis obat yang digunakan. Obat kemoterapi dapat menghancurkan sel leukemia dengan berbagai mekanisme namun tidak bersifat selektif sehingga sel yang normal yang aktif akan membelah juga terkenah pengaruh seperti pada sel di saluran gastrointestinal. Pada kemoterapi fase induksi obat yang digunakan seperti daunorubisin, metotreksat dan sitoin arabnosida dengan pemberian dosis tinggi akan menyebabkan ulserasi mukosa khususnya pada saluran cerna berupa stomatisasi, diare, anoreksia, serta mual dan muntah. Hal ini didukung oleh penelitian Ariawati et $\mathrm{al}^{23}$ yang menunjukkan bahwa keluhan mual, muntah, stomatisasi, diare banyak terjadi pada fase induksi minggu ke-5 setelah pemberian metotreksat. Mual dan muntah diakibatkan karena beberapa hal yaitu aktivasi aferen viseral simpatis, aferen perifer, chaemoreceptor trigger zone, maupun stimulasi korteks serebri yang memengaruhi neurotransmiter pada pusat muntah. Obat L-Asparaginase juga akan menyebabkan penurunan berat badan. Namun, pada penelitian ini terdapat juga beberapa pasien LLA berada pada kategori normal. Menurut teori, pasien LLA akan 
mendapatkan obat prednison pada fase induksi. Obat prednison merupakan obat golongan kortikosteroid dengan pemberian secara oral. Pemberian steroid jangka waktu pendek akan memberikan dampak positif yaitu peningkatan selera makan dan efek lainnya seperti moon face, retensi cairan, perubahan mood dan penambahan berat badan. $^{18}$

Peningkatan berat badan akan memperbaiki asupan makanan pada anak yaitu cenderung lebih baik sehingga membuat anak termasuk pada kategori status nutrisi baik. Hal ini sesuai dengan penelitian Astriningrum $^{15}$ yang menyimpulkam bahwa terdapat hubungan yang kuat dan bermakna antara tahap induksi serta tahap rumatan/maintenance dengan status gizi penderita LLA. Pada penelitian Ramadhani $^{20}$ dengan uji Kolmogrov-Smirnov didapatkan nilai $\mathrm{p}=0,460$ sehingga disimpulkan bahwa fase kemoterapi dengan status gizi anak leukemia tidak terdapat hubungan bermakna.

Penelitian yang dilakukan Raubun ${ }^{24}$ menyatakan bahwa selain efek pengobatan, penurunan status gizi diakibatkan karena sel-sel kanker dapat mengambil zat-zat gizi dari tubuh pasien sehingga mengganggu dalam mempertahankan kecukupan gizi. Oleh karena itu, dalam teori dikatakan bahwa baik penyakit maupun terapinya dapat mengakibatkan pasien mengalami kehilangan nutrisi. Sejumlah gejala pengobatan anti-kanker juga dapat mengganggu nafsu makan pasien dan kemam-puan untuk makan serta mencerna makanan. ${ }^{25}$

Pada beberapa penyakit termasuk kanker, yang mendasari perkembangan malnutrisi ialah ketidakseimbangan energi yang diakibatkan karena asupan makanan dan tingkat penyerapan termasuk malabsorpsi yang kurang sedangkan kebutuhan meningkat sehingga muncul ketidaksesuaian dan terjadi penurunan berat badan serta hilangnya massa otot yang bermanifestasi sebagai malnutrisi. ${ }^{26}$ Penelitian Wolley et $\mathrm{al}^{27}$ mengungkapkan terdapat beberapa faktor yang menyebabkan malnutrisi pada anak dengan kanker yaitu faktor spesifik dari penyakit, faktor yang berhu- bungan dengan pasien itu sendiri seperti pola makan pasien, dan faktor yang berhubungan dengan pengobatan yang dijalankan oleh pasien itu sendiri. Untuk mencegah terjadinya hal, maka status gizi anak leukemia harus menjadi perhatian. Selain dari dokter, perawat dan tenaga medis lainnya, orang tua pasien harus berperan aktif dalam memperhatikan kondisi anak penderita LLA termasuk status gizi. Hasil penelitian ini memperlihatkan bahwa persentase status gizi underweight paling banyak. Peneliti berasumsi bahwa kemungkinan salah satu penyebab buruknya status gizi anak penderita LLA ialah pengetahuan orang tua yang masih kurang. Pada masa kemoterapi induksi, orang tua belum mengetahui proses pengobatan, efek terapi, dan penanganan terhadap efek samping yang terjadi akibat terapi. Orang tua masih dalam proses penyesuaian terhadap kondisi anak.

Dilihat dari pencapaian remisi berdasarkan IMT pasien yang telah di kategorikan dalam status gizi didapatkan untuk kategori underweight yang telah mengalami remisi $47,4 \%$ dan tidak mengalami remisi 52,6\%; kategori normal yang telah mengalami remisi sebanyak $27,3 \%$ dan tidak mengalami remisi $72,7 \%$; sedangkan untuk kategori overweight yang telah mengalami remisi sebanyak $100 \%$. Hal ini sesuai dengan teori yang menyatakan bahwa pada pasien LLA dengan status gizi underweight dan status gizi overweight atau obesitas cenderung sulit untuk mencapai remisi; hubunganya terletak pada peran adiposit dalam fungsi metabolik, sistem imun, dan fisiologi endokrin. Adiposit merupakan sumber poten sitokin proinflamasi sehingga saat sel imun alami terganggu maka akan memicu pelepasan mediator kimia seperti sitokin yaitu TNF- $\alpha$ dan interleukin dan peningkatan secara berlebihan sitokin tersebut dapat mengganggu metabolisme gizi. Hal ini akan berlanjut memicu gangguan terhadap saluran cerna yang mengakibatkan anoraksia dan terjadi penurunan berat badan yang memengaruhi nilai IMT atau status gizi pasien. Status gizi yang kurang atau lebih 
akan mengakibatkan defisiensi zat-zat dalam membangun sistem imun, namun sebaliknya akan memicu peningkatan toksisitas terapi dan insiden febril netropenia. ${ }^{26}$ Pasien LLA yang mengalami obesitas, akan meningkatkan stres oksidatif dan kerusakan oksidatif pada DNA melalui proses inflamasi yang terjadi sehingga dapat meningkatkan risiko kanker pada obesitas. ${ }^{28} \mathrm{Hal}$ inilah yang mengakibatkan induksi kemoterapi tertunda sehingga pasien dengan status gizi underweight, overweight serta obesitas tidak dapat mencapai remisi. ${ }^{21}$

Remisi atau tidak remisinya seorang anak setelah menjalani kemoterapi fase induksi perlu diperhatikan karena menjadi salah satu penentu prognosis LLA sehingga angka kematian anak penderita LLA akan menurun sebaliknya angka harapan hidup anak penderita LLA akan meningkat.

Berdasarkan kategori status gizi tersebut, kemudian dilihat apakah pasien mengalami remisi atau tidak setelah diberikan kemoterapi awal, dalam hal ini ialah kemoterapi fase induksi. Dinyatakan remisi bila setelah menjalani kemoterapi fase induksi, pasien sudah tidak memperlihatkan gejala penyakit dan telah bebas dari gejala klinik LLA, dalam pemeriksaan aspirasi sumsum tulang belakang ditemukan jumlah sel blas $<5 \%$ dari sel berinti, kadar hemoglobin $>12 \mathrm{~g} / \mathrm{dl}$ tanpa transfusi, hitung jenis leukosit didapatkan jumlah leukosit $>3000 / \mu 1$, jumlah granulosit 2000/ $\mu 1$, jumlah trombosit $>100.000 / \mu 1$, dan pada saat pemeriksaan cairan serebrospinal didapatkan hasil normal. ${ }^{3,8}$

Uji korelasi Spearman dilakukan untuk mengetahui hubungan antara IMT dengan tercapainya remisi pada anak penderita LLA. Hasil yang diperoleh ialah $r=0,040$ yang menunjukkan hubungan yang lemah antara IMT dan remisi (negatif). Berdasarkan nilai $\mathrm{p}=0,799(>0,05)$ dapat disimpulkan bahwai tidak terdapat hubungan bermakna antara IMT dan tercapainya remisi pada anak penderita LLA.

Pasien LLA yang telah mengalami remisi setelah dilakukan kemoterapi fase induksi, memiliki peluang untuk dapat mengalami relaps. Dikatakan bahwa pasien yang memiliki respon lambat setelah kemoterapi fase induksi kemungkinan besar akan gagal untuk mencapai remisi dalam waktu 4-6 minggu dan memiliki risiko relaps lebih besar. $^{29}$ Menurut National Cancer Institute, relaps adalah kembalinya suatu penyakit atau tanda dan gejala suatu penyakit setelah masa perbaikan. ${ }^{30}$ Relaps dibedakan menjadi dua yaitu relaps awal yaitu relaps yang terjadi selama pengobatan atau 6 bulan dalam masa pengobatan dan relaps lambat terjadi lebih dari 6 bulan setelah pengobatan. ${ }^{31}$

Menurut penelitian Viana et $\mathrm{al}^{32}$ penderita leukemia dengan gizi buruk berisiko untuk relaps jauh lebih tinggi dibandingkan penderita leukemia yang memiliki status gizi baik, sehingga disimpulkan bahwa status gizi memengaruhi faktor prognosis. Hal ini tidak sesuai dengan penelitian yang dilakukan oleh Meidiana ${ }^{31}$ terhadap faktor kejadian relaps pada anak dengan leukemia yang mendapatkan tidak ada hubungan bernakna antara status gizi dengan kejadian relaps. Namun dalam penelitian ini, pasien yang telah mengalami remisi dan kemudian relaps tidak dijadikan sebagai sampel karena termasuk kriteria eksklusif.

Dalam penelitian ini terdapat beberapa hambatan yaitu dalam proses pengumpulan data rekam medik di Instalasi Rekam Medik antara lain beberapa nomor rekam medik yang tidak sesuai dengan diagnosis sehingga memerlukan waktu lama untuk mendapatkan dokumen rekam medik tersebut. Data yang dikumpulkan bersifat retrospektif yaitu tahun 2015-2018 sehingga untuk satu responden dapat terdiri lebih dari satu status rekam medik. Hal ini dikarenakan pasien sudah menjalani pengobatan dalam jangka waktu lama. Selain itu, hasil perhitungan IMT tidak didapatkan dalam rekam medik dan sebagian rekam medik pasien belum digolongkan pada kategori status gizi.

Keterbatasan dalam penelitian ini ialah 52 sampel penelitian tidak mewakili semua kategori status gizi karena tidak terdapat sampel yang mewakili kategori status gizi obesitas. 


\section{SIMPULAN}

Tidak terdapat hubungan antara indeks massa tubuh dengan tercapainya remisi pada pasien leukemia limfoblastik akut di Pusat Kanker Anak Estella RSUP Prof. Dr. R. D. Kandou Manado..

Bagi perawat dan tenaga medis, diharapkan dapat memperhatikan status gizi penderita LLA dari awal penyakit didiagnosis, selama periode pengobatan, bahkan setelah pasien selesai menjalani pengobatan. Perlu juga pemberian nutrisi secara langsung maupun tidak langsung untuk dapat mempertahankan status gizi pasien agar menjadi lebih baik. Penelitian mengenai faktor yang memengaruhi hubungan indeks massa tubuh pasien dengan tercapainya remisi pada anak penderita leukemia limfoblastik akut juga perlu dilakukan. Disarankan juga untuk melakukan penelitian serupa di rumah sakit yang lain tetapi sebaiknya sampel yang digunakan dapat mewakili semua kategori indeks massa tubuh.

\section{Konflik Kepentingan}

Penulis menyatakan tidak terdapat konflik kepentingan dalam studi ini.

\section{DAFTAR PUSTAKA}

1. Li J, Thompson T, Miller J, Pollack L, Stewart S. Cancer incidence among children and adolescents in the United States, 2001-2003. Pediatrics. 2008; 121:147077

2. Permono B, Ugrasena IDG. Leukemia akut. Dalam: Permono B, Sutaryo, Ugrasena, Windiastuti E, Abdulsalam M. Buku Ajar Hematologi-Onkologi Anak. Jakarta: Ikatan Dokter Anak Indonesia, 2005; p. 236-47.

3. Fridayenti, Masdar H, Asriani S. Profil pasien leukemia anak di RSUD Arifin Achmad Provinsi Riau periode tahun 2013-2014. JIK. 2015;9(2):78-86.

4. American Cancer Society. Acute lymphocytic leukemia (ALL). 2019 [cited 2019 Dec 2]. Availabe from: https://www. cancer. org/cancer/leukemia-in-children/ treating.html

5. Rachmawati F. Hubungan status gizi dengan frekuensi hospitalisasi pasien leukemia limfositik akut pada anak prasekolah di
RSUD Dr. Moewardi [Skripsi]. Surakarta: Universitas Muhammadiyah Surakarta; 2014.

6. Susanti H. Hubungan indeks massa tubuh (IMT) dengan tahapan kemoterapi pada penderita leukemia limfoblastik akut (LLA) anak di RSUPH Adam Malik pada tahun 2009-2014 [Skripsi]. Medan: Universitas Sumatera; 2014.

7. Liem EF, Mantik M, Rampengan N. Hubungan kadar hemoglobin dan tercapainya remisi pada anak penderita leukemia akut. Jurnal Medik dan Rehabilitasi. 2019;1(3):1-7.

8. Lanzkowsky P, Lipton J, Jonathan D. Manual of Pediatric Hematology and Oncology. London: Academic Press Elsevier, 2016; p. 367-405.

9. Weir RJJ, McColl JH, Gibson BE. Prevalancce of protein-energy malnutrition at diagnosis in children with acute lymphoblastic leukemia. Journal Pediatric Gastroenterol Nutr. 2003;8(6).

10. Lange BJ, Gerbing RB, Feusnen J, Sklonik J, Sacks H, Smint Fo, et al. Mortality in overwight and underweight children with acute myeloid leukemia SAMA. 2005;293:203-11.

11. Burturni, A. Oorey F, Gaynon P, Fu C, Franklin J, Siegels, et al. Obesity and body weight independently predict relapse and survival in preadolescent and teenagers with acute lymphoblastic leukemia (ALL): A restrospective analysis of five children cancer group (CCG) studies. Blood. 2004;104: Abstract 952.

12. Gatot D, Windiastuti E. Treatment of childhood acute lymphoblastic leukemia in Jakarta: Result of modified Indonesia National Protocol 94. Paediatr Indones. 2006;46:179-84

13. Hijaya N, Panettta JC, Zhou Y, Kyzer EP, Howard SC, Jeha S, et al. Body mass index does not influence pharmacokinetics or outcome of treatment in children with acute lymphoblastic leukemia. Blood. 2006;108:3997-4002

14. Centers for disease control and prevention. Body mass index (BMI). 2015 May 15 [cited 2019 Sep 6]. Available from: https://www.cdc.gov/healthyweight/ass essing/bmi/

15. Astriningrum M. Hubungan tahap kemoterapi pada penderita leukemia limfo- 
blastik akut dengan status gizi di bangsal Ilmu Kesehatan Anak RSUD. DR. Moewardi [Skripsi]. SurakartaL Universitas Sebelas Maret; 2011.

16. Notoatmodjo S. Teknik pengambilan sampel. Metodologi Penelitian Kesehatan (Cetakan kedua, Edisi revisi). Jakarta: Rineka Cipta, 2002; p. 88-9.

17. Rudolph MA, Hoffman IJ, Rudolph DC. Buku Ajar Pediatri Rudolph (20th ed). Jakarta: EGC, 2006; p. 1395-409.

18. Wong DL, Hockenberry-Eaton M, Wilson D, Winkelstein ML, Schwartz P. Buku Ajar Keperawatan Pediatrik Wong (6th ed). Jakarta:EGC, 2008; p. 482-9.

19. Tehuteru ES. Gambaran tingkat remisi pada leukemia limfoblastik akut setelah fase induksi di bangsal kanker anak RS Kanker Dharmais. Indonesia. Journal of Cancer. 2011;5(4):160.

20. Ramadhani SR, Amir Y, Nurchayati S. Hubungan fase kemoterapi dengan status gizi anak leukemia. JOM FKp. 2018;5(2):374.

21. Voute PA, Barret A, Stevens MCG, Canon HN. Cancer in Children, Clinical Management (3rd ed). Oxford: Springer-Verlag, 2005; p. 138-42,

22. Roganovic J. Acute lymphoblastic leukemia in children. 15 May 2013. [cited 2019 Aug 28]. Available from: https://www. intechopen.com/books/leukemia/acutelymphoblastic-leukemia-in-children

23. Ariawati K, Gatot WD. Toksisitas kemoterapi leukemia limfoblastik akut pada fase induksi dan profilaksis susunan saraf pusat dengan metotreksat 1 gram. Sari Pediatri. 2007;9:252-8.

24. Raubun L. Penatalaksanaan Diet pada
Penyakit Kanker. Bandung: Prosiding, 2005.

25. Omlin A, Blum D, Wierecky J, Haile SR, Ottery FD, Strasser F. Nutrition impact symptoms in advanced cancer patients: Frequency and spesific interventions, a case control study. Journal of Cachexia, Sarcopenia and Muscle. 2013;(5):5561.

26. National Cancer Institute. 2019. Definition Relapse. 2019. [cited 2019 Dec 5]. Available from: https://www.cancer. gov/search/results

27. Wolley NG, Gunawan S, Warouw S. Perubahan status gizi pada anak dengan leukemia limfoblastik akut selama pengobatan. e-CliniC. 2016;4(1).

28. McMillan DC, Sattar N, Lean M, McArdle CS. Obesity and cancer. BMJ 2006; 333:1109-11.

29. Pui C, Campana D. New definition of remission acute lymphoblastic leukemia. Mini-review. 2000;14:783-5.

30. Hong K, Yan E, Chen S, Li Z, Heber D. Obesity and cancer: Inflamation and molecular pathogenesis. Obesity Manag. 2007;3:115-20.

31. Bangun M. Analisis faktor kejadian relapse pada anak dengan leukemia di RSUPN Dr. Cipto Mangunkusumo Jakarta [Tesis]. Jakarta: Universitas Indonesia; 2012.

32. Viana MB, Fernandes RA, de Carvalho RI, Murao M. Low socio-economic status is a strong independent predictor of relapse in childhood acute lymphoblastic leukemia. Int J Cancer Suppl. 1998;11:56-61. 